\title{
Legumes have a higher root phosphatase activity than other forbs, particularly under low inorganic $P$ and $N$ supply
}

\author{
Harry Olde Venterink
}

Received: 24 March 2011 / Accepted: 17 May 2011 / Published online: 14 June 2011

(C) Springer Science+Business Media B.V. 2011

\begin{abstract}
Recent studies suggest that phosphatase activity in soil under legumes is higher than under other plants, but whether this is due to plant activity, microbe activity, or a response to altered soil $\mathrm{N}$ or $\mathrm{P}$ is unclear. I addressed two main questions: (i) do legumes have a higher root phosphomonoesterase (PME) activity than non-legumes?, and (ii) does root PME activity of legumes and non-legumes respond differently to variation in $\mathrm{P}$ or $\mathrm{N}$ supply? In four greenhouse experiments, I compared PME activity of seven leguminous forbs and nine other herb species (mostly forbs), under various supplies of inorganic $\mathrm{P}$ or N. Under low P and high N supply, legumes had on average a $50 \%$ or $120 \%$ higher PME activity than other forbs (expressed per fresh or dry roots). Legumes were similar or more plastic in their response to gradients of $\mathrm{P}$, but less plastic to gradients of N. Root PME activity did not seem to depend on the presence of nodules, nor on growing in species monocultures or mixtures. On average leguminous forbs do have a higher root PME activity than other
\end{abstract}

Responsible Editor: Michael Denis Cramer.

Electronic supplementary material The online version of this article (doi:10.1007/s11104-011-0834-7) contains

supplementary material, which is available to authorized users.

H. Olde Venterink $(\bowtie)$

Institute of Integrative Biology, ETH Zurich,

Universitätsstrasse 16,

8092 Zurich, Switzerland

e-mail: harry.oldeventerink@env.ethz.ch forbs, particularly under low inorganic $\mathrm{P}$ and $\mathrm{N}$ supply. Under higher $\mathrm{N}$ supply, the difference between leguminous and non-leguminous forbs becomes smaller, and PME activity of grasses may even be higher than that of legumes. The results help explaining why legumes can become abundant in plant communities on $\mathrm{P}$ and $\mathrm{N}$-poor soils.

Keywords Enzyme $\cdot$ N:P stoichiometry

Phosphomonoesterase $\cdot$ Nitrogen fixation $\cdot$ Fabaceae

\section{Introduction}

Many leguminous plants live in symbiotic association with $\mathrm{N}_{2}$-fixing rhizobia bacteria, which enables them to use atmospheric- $\mathrm{N}_{2}$ as a resource for growth, and makes them well-adapted to N-poor soil conditions (Vitousek et al. 2002). However, because $\mathrm{N}_{2}$-fixation can induce P-limitation (Cech et al. 2008), we might expect legumes to negatively influence the suitability of their own habitat. Nevertheless, field observations show that legumes are not only widespread in some $\mathrm{N}$-limited ecosystems, but sometimes become abundant in putatively P-limited ecosystems such as some South American forests and savanna vegetation (Perreijn 2002; Ter Steege et al. 2006; Simon et al. 2009).

Houlton et al. (2008) presented a unifying framework for terrestrial $\mathrm{N}_{2}$-fixation that attributed the presence of $\mathrm{N}_{2}$ fixers in P-limited ecosystems to their 
ability to invest $\mathrm{N}$ in the acquisition of $\mathrm{P}$. They supported this idea with published data showing that phosphatase activity tended to be higher in soil collected from under legumes than from under other plants. However, based on this soil observation it remains unclear whether the observed higher phosphatase activity was due to activity of the legumes roots, or to soil microbial activity, possibly induced by the plants. Rather little is known about the root phosphatase activity of legumes. Yadav and Tarafdar (2001) observed that phosphatase activity was higher in a mixture of three legume species than in mixtures of three cereals or of three oilseed crops, but only at a very young age, i.e., less than 3 weeks after germination. Higher phosphatase activity has also been demonstrated in the leguminous crops bean Vicia faba L. and chickpea Cicer arietinum L. than in co-occurring maize Zea mays L. and wheat Triticum aestivum L. (Li et al. 2004, 2007); however, Li et al. (1997) and Hayes et al. (1999) found that the phosphatase activity of legumes was lower than or similar to that of several other plants, mainly grasses. Hence, there is a need for a systematic comparison between legumes and non-legumes in their root phosphatase activity.

Plants do not have a constant phosphatase activity, but respond to environmental conditions such as variation in soil $\mathrm{P}$ and $\mathrm{N}$ availabilities. Generally, root phosphatase activity increases as either soil $\mathrm{P}$ availability decreases or $\mathrm{N}$ supply increases ( $\mathrm{Li}$ et al. 1997; Hayes et al. 1999; Treseder and Vitousek 2001; Phoenix et al. 2004; Fujita et al. 2010; Olde Venterink and Güsewell 2010). These effects can both be seen as responses to increased $\mathrm{P}$ limitation, since $\mathrm{N}$ and $\mathrm{P}$ are the most common growth-limiting nutrients in terrestrial ecosystems (Elser et al. 2007). Since legumes can increase soil $\mathrm{N}$ or reduce soil $\mathrm{P}$ availabilities (Binkley 1997; Yelenik et al. 2004; Cech et al. 2008), the observed higher soil phosphatase activity under legumes of Houlton et al. (2008) might have been a response to altered soil $\mathrm{N}$ and $\mathrm{P}$ availabilities, rather than an inherent difference in phosphatase activity of the plant groups. Hence, when comparing phosphatase activities of legumes and other plants, it would be good to investigate these activities under a range of $\mathrm{P}$ and $\mathrm{N}$ availabilities. Because legumes are able to fix atmospheric-N, they could respond differently from non-legumes to changes in their $\mathrm{N}$ supply, though this has not been investigated.
Here, I present the results of four greenhouse experiments involving seven European leguminous forb species and nine non-legume herb species (mainly forbs), carried out under various conditions of inorganic $\mathrm{P}$ and $\mathrm{N}$ supply. I addressed two main research questions: (i) do legumes have a higher root PME activity than non-legumes?, and (ii) do legumes and non-legumes respond differently in terms of PME activity to variation in $\mathrm{P}$ or $\mathrm{N}$ supply? Additionally, I examined whether root PME activity is affected by the presence of root nodules or of other species.

\section{Materials and methods}

In March-May 2010, I carried out an experiment (experiment 1) in a glasshouse in Zurich to compare the root PME activities of seven leguminous forb species (Vicia cracca L., Trifolium pratense L., Onobrychis viciifolia Scop., Medicago lupulina L., Lupinus albus L., Lotus corniculatus L., Lathyrus pratensis L. (all Fabaceae)) and seven nonleguminous forb species (Silene vulgaris (Moench) Garcke S.L. (Caryophyllaceae), Ranunculus bulbosus L. (Ranunculaceae), Plantago lanceolata L. (Plantaginaceae), Leontodon autumnalis L. (Asteraceae), Leucanthemum vulgare Lam. (Asteraceae), Centaurea jacea L. (Asteraceae), Achillea millefolium L. (Asteraceae)). All species occur in European grassland and, apart from Lupinus albus, are native to Europe. The experiment was carried out with plants that had been grown for 8 weeks in $0.4 \mathrm{~L}$ pots filled with quartz sand containing no detectable $\mathrm{N}$ or $\mathrm{P}$. Each pot contained one plant, and was placed in a separate container in which water was supplied every 1 to 3 days as necessary to prevent water stress. The plants were germinated from seeds 2-3 weeks prior to the experiment. In this experiment, I aimed to compare the maximal PME activities of these species, and therefore grew the plants with very little $\mathrm{P}$, an excess of $\mathrm{N}$, and non-limiting doses of other macro- and micronutrients ( $\mathrm{K}, \mathrm{Ca}, \mathrm{Mg}, \mathrm{S}, \mathrm{Fe}, \mathrm{Bo}, \mathrm{Mn}, \mathrm{Zn}$, Mo and $\mathrm{Cu}$; for forms and doses see (Olde Venterink and Güsewell 2010)). Thus, the pots received $0.2 \mathrm{mg} \mathrm{P}$ (total in 8 weeks applied as $\mathrm{NaH}_{2} \mathrm{PO}_{4}$ ) and $128 \mathrm{mg} \mathrm{N}$ (applied as $\mathrm{NaNO}_{3}$ ), yielding a $\mathrm{N}: \mathrm{P}$ supply mass ratio of 640. Although the plants experienced severe $\mathrm{P}$ limitation over an 8 week period, they showed no sign of senescence observed in older plants grown under 
these conditions (see e.g. Güsewell 2005; Olde Venterink and Güsewell 2010). In addition, I created a second $\mathrm{P}$ treatment for these 14 species by adding $8.5 \mathrm{mg} \mathrm{P}$ per pot, and otherwise kept the same conditions, which yields the balanced N:P ratio of 15 where neither $\mathrm{P}$ nor $\mathrm{N}$ are severely limiting. The solutions were applied in weekly doses $2.5 \mathrm{ml}$ of the solutions in the first 2 weeks, $5 \mathrm{ml}$ in the middle period, and $7.5 \mathrm{ml}$ in the last 2 weeks, to take into account that plants need increasing amounts of nutrients as they grow. All combinations of species and $\mathrm{P}$ treatments were carried out in duplicates. Plants grew under natural light conditions in a glasshouse (no additional light was supplied).

In addition, I set up two other experiments to investigate root PME activity of leguminous and nonleguminous herb species (mainly forbs) along a gradient of $\mathrm{P}$ supply or a gradient of $\mathrm{N}$ supply. These experiments were conducted in the same greenhouse and during the same period as the comparative experiment. In experiment 2, I studied PME activity of six species along a $\mathrm{P}$ gradient. The $\mathrm{P}$ supply gradient consisted of a total of $0.2,1,5,8.5,10,25$ or $50 \mathrm{mg} \mathrm{P}$ per pot in 8 weeks, supplied as $\mathrm{Na}_{3} \mathrm{PO}_{4}$ solution in weekly doses of $2.5-7.5 \mathrm{ml}$. All pots of the $\mathrm{P}$ gradient had the same $\mathrm{N}$ supply as in the comparative experiment (i.e. $128 \mathrm{mg} \mathrm{N}$ ) and other growth conditions were also the same. The $\mathrm{P}$ gradient experiment was carried out with the legumes Trifolium pratense, Medicago lupulina and Onobrychis viciifolia, and the non-legume forbs Plantago lanceolata, Achillea millefolium and Centaurea jacea. In experiment 3, I studied PME activity of four species along a $\mathrm{N}$ gradient. The $\mathrm{N}$ supply gradient consisted of a total of $1,2,4,8,16,32,64$, or $128 \mathrm{mg} \mathrm{N}$ per pot in 8 weeks, supplied as $\mathrm{NaNO}_{3}$ solution in weekly doses of 2.5-7.5 ml. Plants did not receive P fertilizer (but some soil, see next paragraph). This experiment was carried out with the legumes Trifolium pratense and Medicago lupulina, the non-legume forb Plantago lanceolata, and the grass Arrhenatherum elatius (L.) Presl. (Poaceae), all with two plants per pot either in monocultures or mixtures of Trifolium-Plantago or Medicago-Arrhenatherum. I included the species mixtures to determine whether PME activity of a species was affected by that of a co-occurring species, either directly or through $\mathrm{P}$ released from the added soil.

In experiment 3 ( $\mathrm{N}$ gradient), it was important that the legumes would be able to build nodules and form associations with $\mathrm{N}$-fixing bacteria, because this might affect their PME activity, particularly under low $\mathrm{N}$ supply. This was different from experiments 1 and 2, in which the $\mathrm{N}$ supply was sufficiently high to suppress the formation of nodules (based on previous unpublished experiments with Trifolium pratense and Medicago lupulina). Thus, in the experiment 3 the quartz sand was inoculated with soil collected in a nearby meadow from beneath plants of Trifolium pratense and Medicago lupulina (5\% volume soil mixed in the sand). The fact that the soil would contain some $\mathrm{N}$ and $\mathrm{P}$ was taken for granted in experiment 3 , but was a reason not to use it for experiments 1 and 2 where I wanted to control the P supply. All other conditions, such as pot size, micronutrients, period were similar in experiments 1,2 , and 3.

A fourth experiment was run in May 2009. Here, I aimed to compare root PME activity of the leguminous forb Medicago lupulina and the non-leguminous forb Plantago media L. (Plantaginaceae) in response to a factorial supply of $\mathrm{N}$ and/or P. This experiment 4 lasted for 18 days, and was carried out with one Medicago plant per pot or three Plantago plants per pot to compensate for the smaller initial size of the latter species. The $0.4 \mathrm{~L}$ pots contained quartz sand, and received either $25 \mathrm{mg} \mathrm{N}$ (applied as $\mathrm{NaNO}_{3}$ ), $1.7 \mathrm{mg} \mathrm{P}$ (applied as $\mathrm{NaH}_{2} \mathrm{PO}_{4}$ ), both $25 \mathrm{mg} \mathrm{N}$ and $1.7 \mathrm{mg} \mathrm{P}$, or only water. The plants were about 10 weeks old. To evaluate whether the presence of nodules affected PME activity of the Medicago plants, all treatments were repeated using plants with nodules and plants from which the all nodules had been removed (five replicates of each). However, at the harvest there was no consistent pattern between plants having nodules and these pre-distinguished groups. Therefore, I harvested five to eight replicates per nutrient treatment, and recorded whether nodules were present. For the Plantago plants, four to five replicates per treatment were used.

The process of harvesting and determining PME activity was the same in all experiments. The roots were first washed to remove sand, and moisture was removed with tissue paper. PME activity was measured using para-nitrophenyl phosphate (pNPP) as substrate (Johnson et al. 1999; Turner et al. 2001; Hogan et al. 2010; Olde Venterink and Güsewell 2010). For this, a $100 \mathrm{mg}$ sample of fresh roots was added to $5 \mathrm{ml}$ of tris(hydroxymethyl)-aminomethane/ 
maleate buffer containing $0.125 \mathrm{M}$ pNPP (pH 6). After one hour of gentle shaking at room temperature, $0.5 \mathrm{ml}$ of each test solution was added to $3-6 \mathrm{ml}$ of $2 \mathrm{~N} \mathrm{NaOH}$. The concentration of para-nitrophenol in the solution was determined by measuring the absorbance at $410 \mathrm{~nm}$ using a photospectrometer (Hach Lange DR2800, Germany). PME activity was calculated as $\mu \mathrm{mol}$ para-nitrophenol produced per $\mathrm{g}$ fresh root mass and per hour, and hence $\mu$ mol pNPP cleaved. Freshweight and dry weight of the remaining roots were determined, in order to enable calculation PME activities per $g$ fresh roots, as well as per $g$ dry roots.

\section{Results}

The average PME activity of the leguminous forbs in experiment 1 was $50 \%$ higher than that of the non-leguminous forbs when expressed per $g$ fresh roots (Fig. 1), and 120\% higher expressed per g dry roots (Online Resource 1). However, the PME activity of some legumes, e.g. Onobrychis viciifolia and Lathyrus pratensis, was not higher than that of other forbs.
The difference in PME activity between the two groups of plants was evident under both a balanced $\mathrm{P}$ supply and under severe $\mathrm{P}$ limitation (i.e. $8.5 \mathrm{mg} \mathrm{P}$ and $0.2 \mathrm{mg} P$ per pot; N:P supply ratios of 15 and 640 , respectively) (Fig. 1). These results are consistent with those of experiment 2 (Fig. 2), showing a decrease in PME activity mainly at high to very high mineral $\mathrm{P}$ supply ( $>10 \mathrm{mg} \mathrm{P}$ per pot). The leguminous forbs Trifolium pratense and Medicago lupulina were more plastic in PME activity in response to P supply than the non-leguminous forbs; for these species the ratio between PME activity at low and high $\mathrm{P}$ supply was 3 to 4, compared to a ratio of around 2 for the non-legumes (Fig. 2). As in experiment 1, Onobrychis viciifolia did not have a higher PME activity than the non-legumes at low P supply, and hence showed a lower plasticity in PME activity than other legumes.

The leguminous forbs generally showed a lower plasticity in PME activity in response to variation in $\mathrm{N}$ supply than the non-legumes. For example, Trifolium pratense showed no response to increasing $\mathrm{N}$ supply, whereas the non-leguminous forbs Plantago media, Plantago lanceola and the grass Arrhenatherum elatius strongly increased PME activity (Figs. 3 and 4). Also, the legume Medicago lupulina

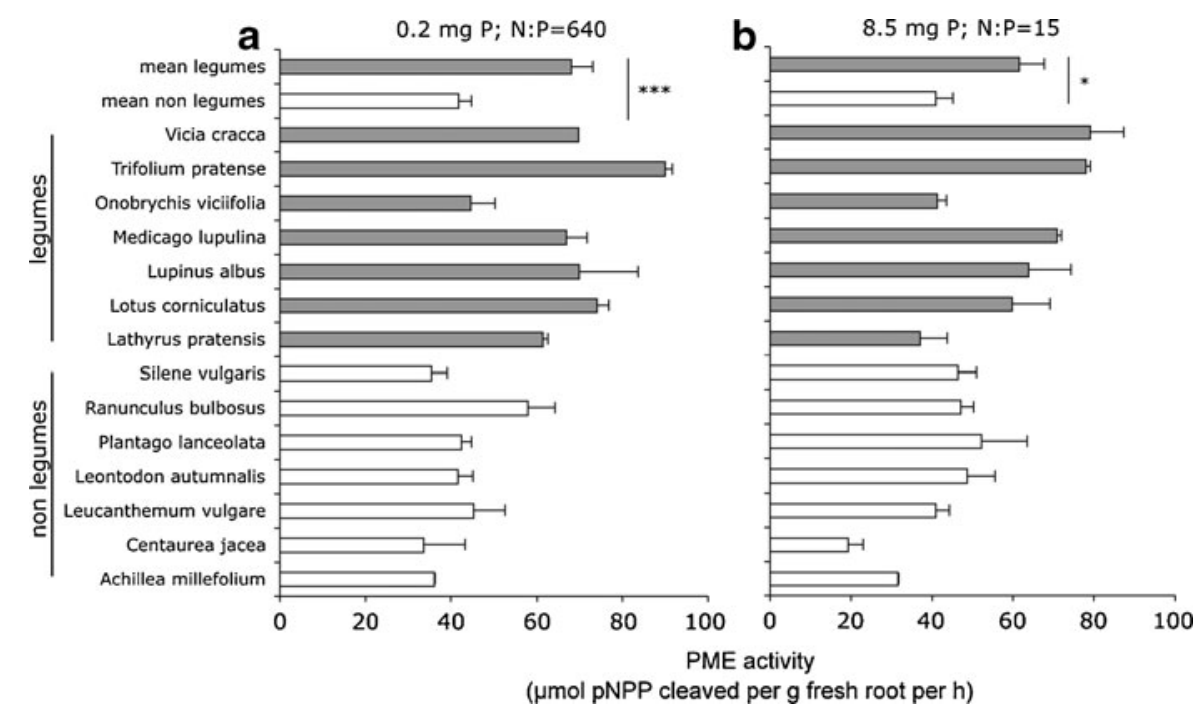

Fig. 1 Phosphomonoesterase (PME) activity of leguminous and non-leguminous forbs under (a) low P supply (0.2 mg P per pot in 8 weeks) or (b) moderate $\mathrm{P}$ supply ( $8.5 \mathrm{mg} \mathrm{P}$ per pot in 8 weeks). At both $\mathrm{P}$ levels, legumes had a higher PME activity than non-legumes $(F=20.5, P<0.001$ and $F=7.2, P=$ 0.020 for low $\mathrm{P}$ and moderate $\mathrm{P}$ supply, respectively). Effects of $\mathrm{P}$ supply, or the interaction between $\mathrm{P}$ supply and functional group were not significant ( $P=0.45$ and $P=0.56$, respectively). Pots were not inoculated with bacteria and the legumes did not contain nodules at the harvest. $\mathrm{P}$ was supplied as $\mathrm{NaH}_{2} \mathrm{PO}_{4}$. They also received $128 \mathrm{mg} \mathrm{N}$ and all other nutrients in surplus amounts. Error bars show SE (of seven replicates for bars of the means (i.e. means of seven species), and two replicates for the bars of the separate species) 
Fig. 2 Phosphomonoesterase (PME) activity of leguminous and non-leguminous forbs along a gradient of $\mathrm{P}$ supply, expressed per $g$ fresh root per hour. $\mathrm{P}$ was applied as $\mathrm{NaH}_{2} \mathrm{PO}_{4}$. They also received $128 \mathrm{mg} \mathrm{N}$ and all other nutrients in surplus amounts. Pots were not inoculated with bacteria, and the legumes did not contain nodules at the harvest. All regressions are significant $(P<0.05)$; best fits were with linear regressions for the legumes and with exponential regression for the non legumes
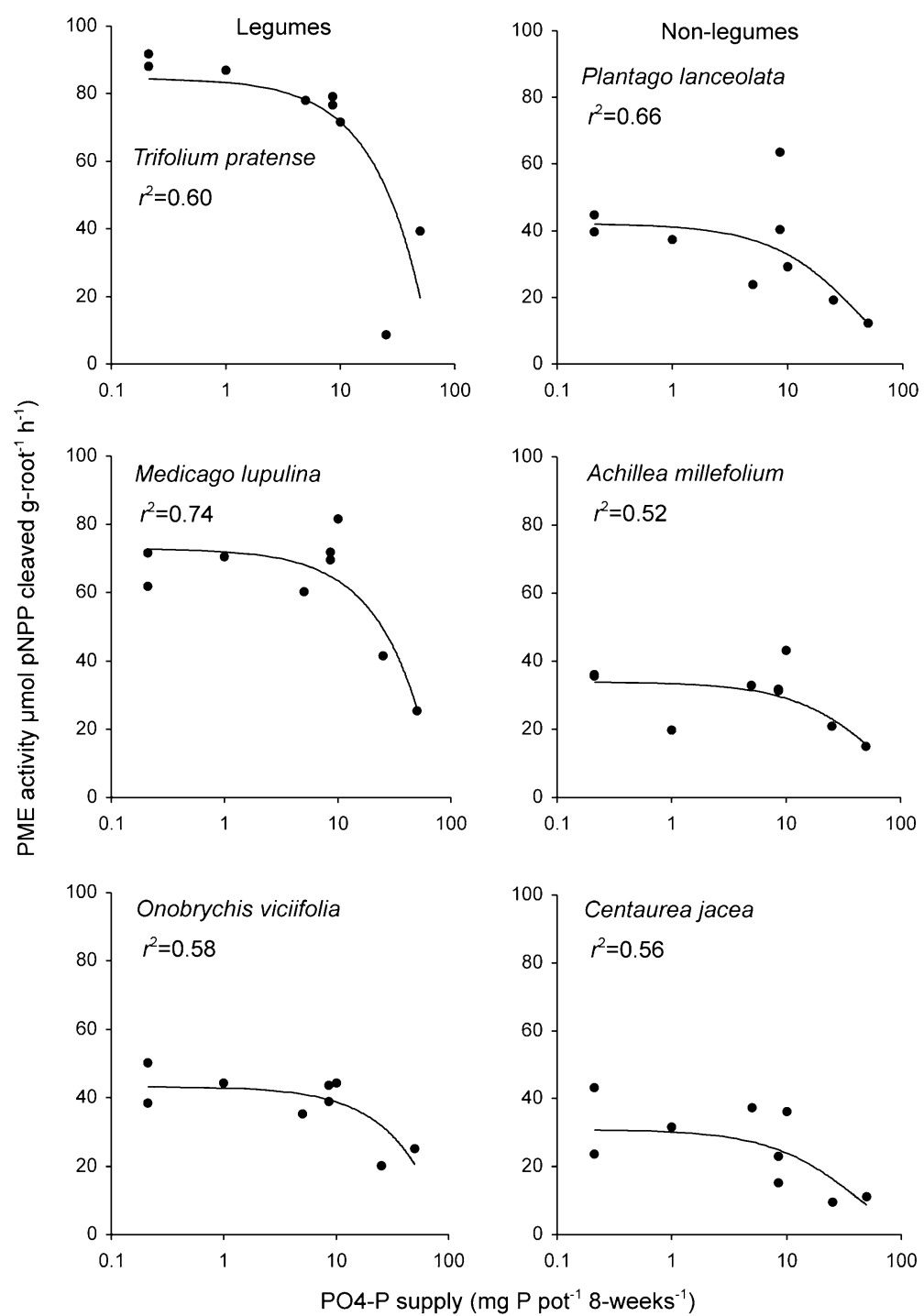

did not respond significantly to $\mathrm{N}$ in the factorial experiment (Fig. 4), but responded to $\mathrm{N}$ supply in the gradient study, albeit less so than the non-legumes (Fig. 3). Hence, the difference in PME activity between leguminous forbs and non-leguminous forbs and the grass was much larger under low $\mathrm{N}$ supply than under high $\mathrm{N}$ supply, although the difference varied among the species.

Seven out of 23 Medicago plants of experiment 4 contained nodules at the harvest (treatments $-\mathrm{P}-\mathrm{N},+\mathrm{P}-\mathrm{N},+\mathrm{P}+\mathrm{N})$; however the presence of nodules had no significant effect upon root $\mathrm{PME}$ activity $(P=0.78)$, and the interaction between nodules and $\mathrm{N}$ or $\mathrm{P}$ supply was also not significant $(P=$
0.32 and $P=0.96$ ). Most of the legumes in experiment 3 were nodulated, but having nodules was not systematically recorded. In another experiment, where the sand was not inoculated with bacteria, 5-6 weeks old Trifolium pratense plants contained no nodules. The PME activity of these plants responded in the same way to $\mathrm{N}$ supply as in Fig. 3a (data not shown). In experiments 1 and 2, the plants were not inoculated with bacteria and, with one exception, the plants did not possess nodules at the time of harvest.

No significant differences in PME activity were recorded between plants in monocultures and in species mixtures for any of the four species in experiment 3 (Fig. 3). 

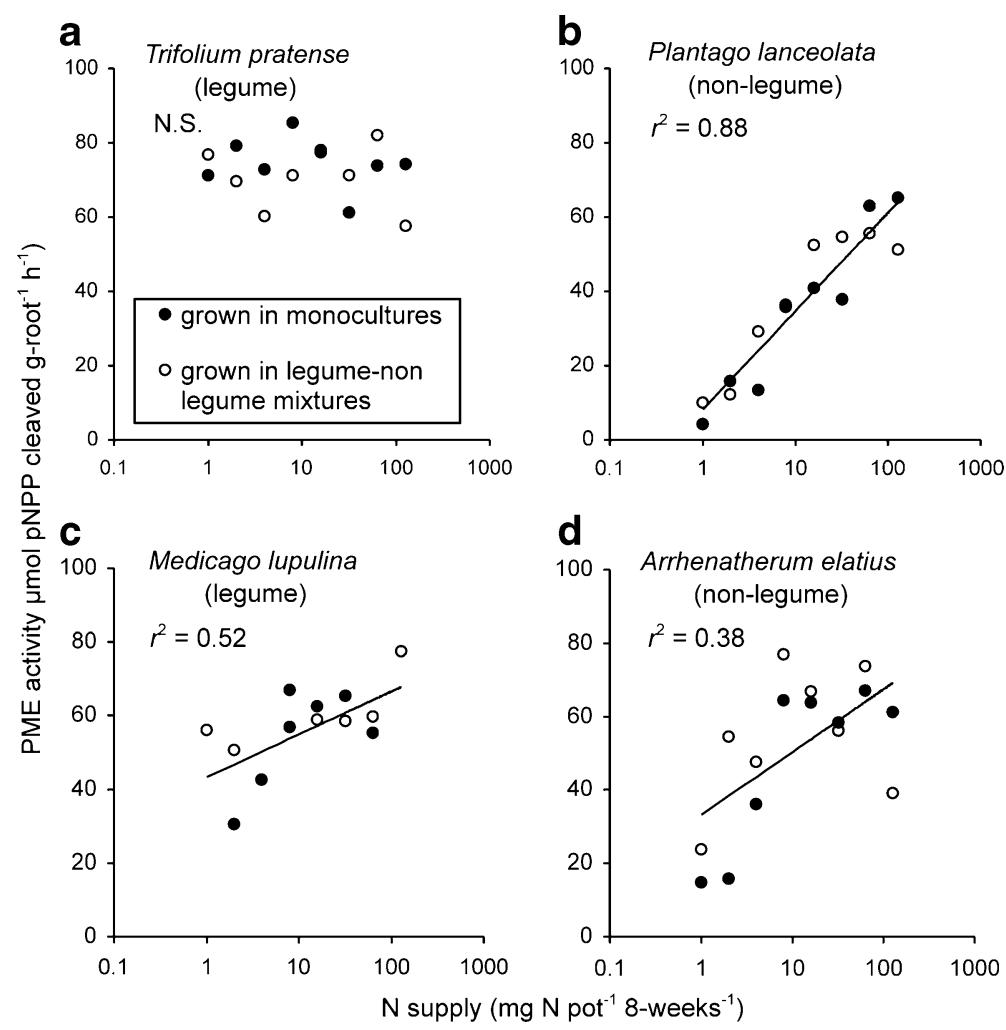

Fig. 3 Phosphomonoesterase (PME) activity of two leguminous and two non-leguminous herbs (the forb Plantago lanceolata and the grass Arrhenatherum elatius) along a gradient of $\mathrm{N}$ supply, expressed per $\mathrm{g}$ fresh root per hour. $\mathrm{N}$ was supplied as $\mathrm{NaNO}_{3}$. Pots also received all other nutrients in surplus amounts, but no P. Pots were inoculated with bacteria, and the legumes contained nodules at the harvest. All drawn

\section{Discussion}

To my knowledge, this is the first systematic comparison of root phosphatase activity in leguminous and non-leguminous forb species. The four experiments revealed that most legumes had a higher PME activity than other forbs. Based on a literature review, Houlton et al. (2008) concluded that phosphatase activity in soil under legumes was usually higher than under other plants (mainly trees but also a grass-forb mixture and a wheat). It remained unclear, however, whether the observed higher phosphatase activity in the soil was due to activity of the legumes roots, or to soil microbial activity, possibly induced by the plants (Houlton et al. 2008). The results of my experiments suggest that the reason for the difference in soil phosphatase activity is likely to be higher phosphatase activity of the legumes themselves, and regressions are significant $(P<0.05)$. One regression per panel was drawn since growing in monoculture or mixture was not significantly different $(P=0.36, P=0.29, P=0.17$ and $P=0.29$ for panels $\mathbf{a}, \mathbf{b}, \mathbf{c}$ and $\mathbf{d}$, respectively, for the factor mixture/ monoculture in ANOVAs with $\log$ (N supply) as co-variable). N.S. not significant $(P=0.59)$

that there is no need to postulate higher soil microbial activity. Yadav and Tarafdar (2001) observed that a mixture of three legume species had a higher phosphatase activity than mixtures of three cereals or of three oilseed crops, but only at a very early stage, i.e., less than 3 weeks after germination. The results presented here show that the higher phosphatase activity of leguminous forbs compared with other forbs is not restricted to these early stages but also occurs in plants up to 3 months old. It is worth emphasizing that not all legume species (e.g. Onobrychis viciifolia in Figs. 1 and 2) had a higher PME activity than the non-legumes, hence the conclusion drawn here counts for the legumes as a functional group, and does not necessarily apply for individual species.

Although this study shows that leguminous forbs have a higher phosphatase activity than other forbs, 


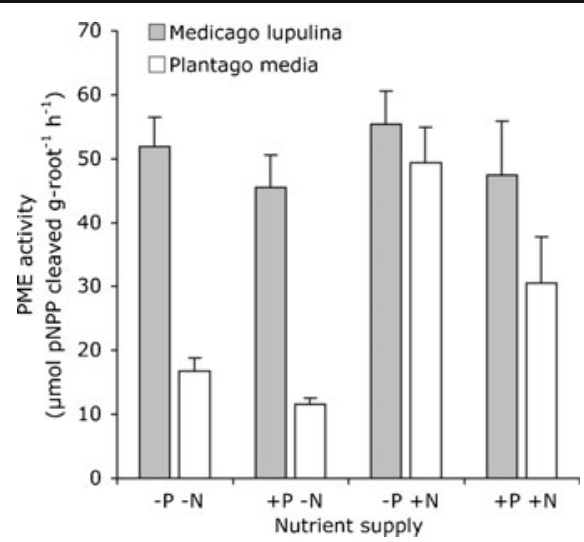

Fig. 4 Phosphomonoesterase (PME) activity of the leguminous forb Medicago lupulina and the non-leguminous forb Plantago media in response to $\mathrm{N}$ and/or $\mathrm{P}$ supply, expressed per $\mathrm{g}$ fresh root per hour. Pots received either $25 \mathrm{mg} \mathrm{N}$ applied as $\mathrm{NaNO}_{3}(-\mathrm{P}$ $+\mathrm{N}), 1.7 \mathrm{mg} \mathrm{P}$ applied as $\mathrm{NaH}_{2} \mathrm{PO}_{4}(+\mathrm{P}-\mathrm{N})$, both $25 \mathrm{mg} \mathrm{N}$ and $1.7 \mathrm{mg} \mathrm{P}(+\mathrm{P}+\mathrm{N})$, or only water $(-\mathrm{P}-\mathrm{N})$. Some of the Medicago plants contained nodules at the harvest. Since having nodules did not significantly affect PME activity $(P=0.78)$, it was not taken into account for this figure. On average, Medicago had a higher PME activity than Plantago $(F=41.1, P<0.001)$. Both $\mathrm{N}$ and $\mathrm{P}$ had significant effects on PME activity of Plantago (N: $F=36.7$, $P<0.001$; P: $F=7.5, P=0.015)$, but not on that of Medicago $(\mathrm{N}$ : $F=0.1 P=0.80 ;$ P: $F=1.5, P=0.24)$. Number of replicates: Medicago five to eight, Plantago four to five

they do not necessarily have a higher activity than all other functional groups of plants. Hayes et al. (1999) found that the PME activity of two grass species was higher than that of three leguminous forbs, and $\mathrm{Li}$ et al. (1997) observed a very high variation in phosphatase and phytase activity among species, but no systematic difference between legumes (nine species) and grasses (six species). I found the PME activity of three grasses (Arrhenatherum elatius, Agrostis capillaris, and Alopecurus pratensis) measured under low $\mathrm{P}$ and high $\mathrm{N}$ supply (this study; Olde Venterink and Güsewell 2010; and unpublished data) to be comparable to, or even higher than, that of leguminous forbs.

The general plant responses of decreasing PME activity with increasing $\mathrm{P}$ supply or decreasing $\mathrm{N}$ supply observed here (Figs. 2, 3 and 4) are consistent with previous studies ( $\mathrm{Li}$ et al. 1997; Hayes et al. 1999; Treseder and Vitousek 2001; Phoenix et al. 2004; Wang et al. 2007; Fujita et al. 2010; Olde Venterink and Güsewell 2010). Based on these patterns, one could conclude that inducing $\mathrm{P}$ limitation, either by reducing $\mathrm{P}$ or increasing $\mathrm{N}$, would stimulate phosphatase activity. However, average PME activity under severely $\mathrm{P}$ limited conditions
(N:P supply ratio 640) was not significantly different from that under balanced $\mathrm{N}$ and $\mathrm{P}$ supply ( $\mathrm{N}: \mathrm{P}$ supply of 15) for either legumes or non-legumes. This indicates that the plasticity in root PME activity is influenced more strongly by a surplus of $\mathrm{P}$ or a shortage of $\mathrm{N}$, than by a shortage of $\mathrm{P}$.

The leguminous forbs in my experiments had a similar or higher plasticity in PME activity than nonleguminous forbs in response to gradients in inorganic P supply (Figs. 1 and 2), but a lower plasticity in response to gradients in $\mathrm{N}$ supply (Figs. 3 and 4). The contrasting plasticity of legumes and non-legumes, particularly in response to $\mathrm{N}$ supply, has not previously been reported, and deserves to be investigated for more species. The results presented here, and summarised in Fig. 5, suggest that the difference in PME activity between leguminous forbs and other herbs, i.e. forbs and grasses, is likely to be greatest when $\mathrm{N}$ and $\mathrm{P}$ are both in short supply. Indeed, under such conditions, which are common in many natural ecosystems (Elser et al. 2007; Vitousek et al. 2010), the difference between leguminous forbs and other forbs or grasses is likely to be greater than the factor 1.5 to $2-2.5$ (based on root fresh or dry weight) that I recorded in experiment 1 . The on average three times higher soil phosphatase activity under legumes than under non-legumes reported by Houlton et al. (2008) is consistent with this idea, although the difference could partly have resulted from greater microbial activity and/or accumulation of phosphatase in the soil (Skujinš and Burns 1976).

Root PME activity of Medicago lupulina was not significantly affected by the presence of nodules (Fig. 4). Also, the low plasticity in PME activity of Trifolium pratense in response to $\mathrm{N}$ supply appeared to be independent of their ability to fix $\mathrm{N}_{2}$, being observed in plants both with (Fig. 3a) and without (data not shown) nodules. Assuming that the results obtained from my relatively young plants are also representative for older life stages, they suggest that, at least for these legume species, the lower plasticity in PME upon $\mathrm{N}$ supply is an inherent trait rather than a response to a higher $\mathrm{N}$ content enabled through $\mathrm{N}_{2^{-}}$ fixation. This corresponds well with McKey's (1994) suggestion that ancestral legumes had a high Ndemanding lifestyle, which ultimately led to the symbiotic association with the $\mathrm{N}_{2}$-fixing rhizobia bacteria. A low plasticity in phosphatase activity implies high costs in terms of $\mathrm{N}$, since phosphatase 


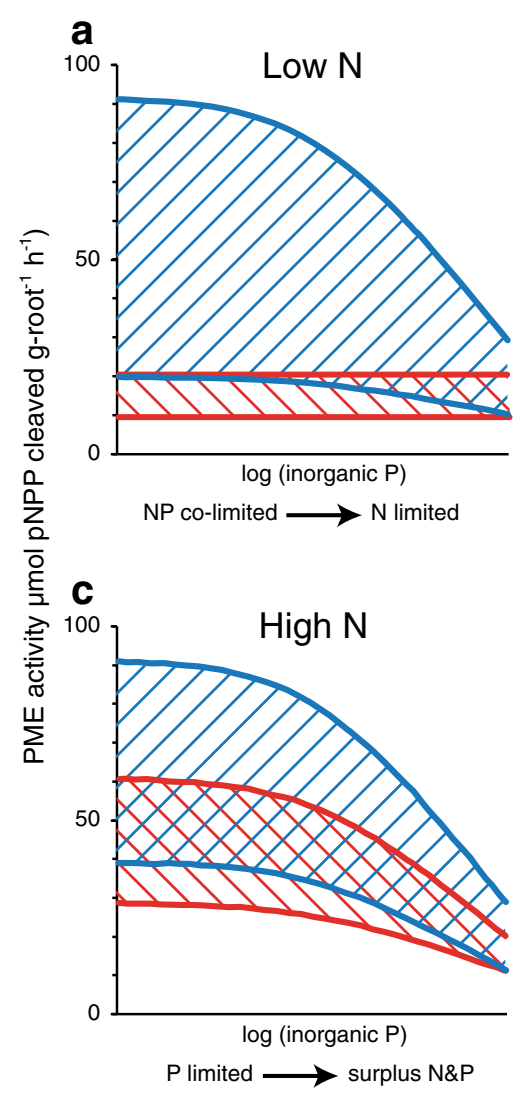

Fig. 5 Ranges (upper and lower limits) of the root PME activities of leguminous and non-leguminous forbs along gradients of inorganic P supply with either low N (a) or high $\mathrm{N}$ supply (c), and along gradients of $\mathrm{N}$ supply with either low $\mathrm{P}$ (b) or high P supply (d). The patterns in panels (b) and (c) are a summary of the results in Figs. 1, 2, 3 and 4. The patterns in panels (a) and (d) are partly a summary, with the responses in

consists of $8-32 \%$ of $\mathrm{N}$ (Treseder and Vitousek 2001), not only at high $\mathrm{N}$ - when species can afford the $\mathrm{N}$-investment to acquire $\mathrm{P}-$ but also at low $\mathrm{N}$ availability. This $\mathrm{N}$-investment at low $\mathrm{N}$ availability only appears to be a competitive strategy if N-losses can be compensated by $\mathrm{N}_{2}$-fixation. The plasticity in PME activity of nodulating and non-nodulating legumes in response to $\mathrm{N}$ availability is worth to be studied for more species and older life stages.

In P-poor soils, symbiotic $\mathrm{N}_{2}$-fixation of leguminous plants has been shown to be constrained by low $\mathrm{P}$ availability (Perreijn 2002; Vitousek et al. 2002). Thus, in soils that are poor in both $\mathrm{N}$ and $\mathrm{P}$, the nonplastic response in PME activity to low $\mathrm{N}$ may help legumes to overcome their initial $\mathrm{P}$ limitation and the constrained $\mathrm{N}_{2}$ fixation. This obviously will only be
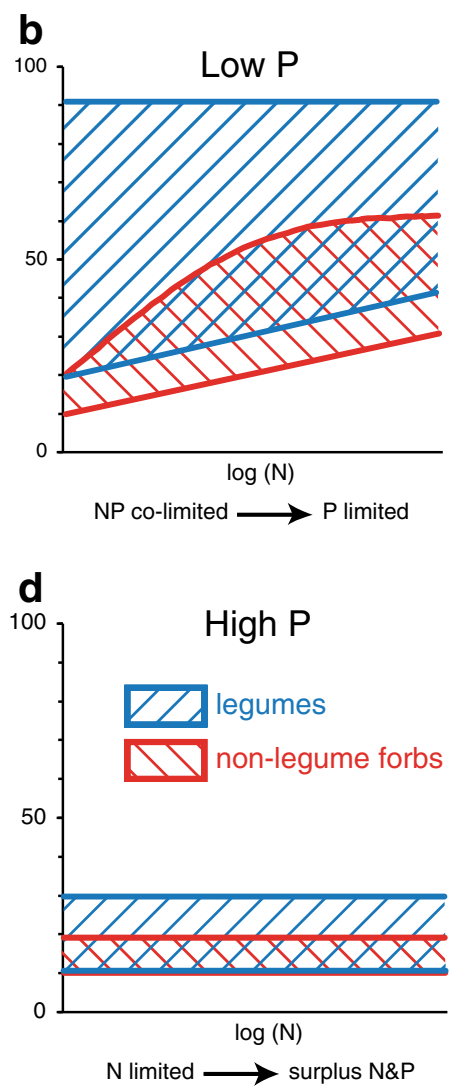

panel (a) at low-N and high-P hypothesized not to be higher than under high-N and high-P, and the responses in panel (d) at high-P and low-N not to be higher than under high-P and highN. PME activity is expressed per weight fresh root; If PME is expressed per unit dry weight, the general pattern is identical, but differences between legumes and non legumes are even more pronounced (cf. Online Resource 1)

successful if the soil contains sufficient amounts of organic-P, and if cleaved $\mathrm{P}$ becomes available for the legumes. In their model simulations of $\mathrm{N}_{2}$-fixing plants in N-limited ecosystems, Wang et al. (2007) observed a feedback towards greater $\mathrm{N}$ investments of $\mathrm{N}_{2}$-fixing plants in phosphatase activity with increasing soil $\mathrm{N}$ availability, and increasing P-limitation, as a result of their $\mathrm{N}_{2}$-fixation. My results suggest that this may not be the case for the leguminous plants, since their PME activity may not respond much to differences in soil $\mathrm{N}$, but the feedback could operate on the level of plant communities because the cooccurring non-legumes may considerably increase PME activity upon increased soil N (Fig. 5). The latter feedback, however, may lead to a different species composition than the first. Noteworthy, 
increased $\mathrm{N}$ availability, through for instance enhanced atmospheric deposition that took place in Western Europe and other parts of the world may also have particularly increased PME activity of non-legumes (cf. Johnson et al. 1999), and not so much that of the legumes, and may therefore have influenced plant community compositions through altered $\mathrm{P}$ availability of the non-legumes.

I found no significant difference in PME activity between plants in monocultures and in species mixtures (Fig. 3). Hence, competing species did not directly influence PME activities of their neighbours, even when their activities were very different, as was the case for Trifolium pratense and Plantago lanceolata under low $\mathrm{N}$ supply. These plants were growing in quartz sand with $5 \%$ soil, so potentially the PME excreted by their roots could have released $\mathrm{P}$ from organic-P in the soil. However, the concentrations of organic-P in the pots were probably too low for any indirect effects upon PME activity to be detectable. Additional experiments with higher doses or treatments of organic-P are required to further explore PME activities of plants in species mixtures.

It has been shown that some legumes crops, such as Vicia faba and Cicer arietinum, facilitate P uptake and biomass production of co-occurring non-legumes crops (Zea mays or Triticum aestivum), apparently by exuding organic acids, protons or acid phosphatase by the legumes ( $\mathrm{Li}$ et al. 2004, 2007). The results presented here, and particularly the differences in plasticity of root PME activity to N supply, suggest that the role of legumes in facilitating $\mathrm{P}$ availability for themselves and/or their competitors, may even be more important in natural ecosystems that are poor in both $\mathrm{N}$ and inorganic $\mathrm{P}$ (cf. Fig. 5). One of the basic model assumptions of Houlton et al. (2008) - that legumes have a higher phosphatase activity than other plants - was supported here with respect to other forbs, and may also hold for grasses for N-poor conditions. Further research is needed to evaluate whether the legumes also differ from non-legumes with respect to phosphodiesterase (PDE) activity, although the limited available information from Hordeum vulgare L., Lolium perenne L., Pinus radiata D. Don. and the lichen Cladonia portentosa (Dufour) Coem. indicates that PDE activity is five to ten times lower than PME activity (Asmar and GisselNielsen 1997; Chen et al. 2002; Hogan et al. 2010), but a recent study with various wetland plants in
Belize showed that the difference between PME and PDE activity can be smaller than that (Rejmánková et al. 2011). Also the role that mycorrhizae might play in PME activity for legumes and other plants under various soil $\mathrm{N}$ and $\mathrm{P}$ conditions is worth investigating. Moreover, mycorrhizal associations might also have influenced the results obtained in this study, but mycorrhizal infection rates or PME activities of mycorrhizae were not measured. Finally, the question of who benefits from the higher PME activity of legumes - the legumes themselves or their competitors? - deserves further study in both agricultural and natural plant communities.

Acknowledgements Experiments 2, 3, and 4 were carried out during Plant Ecology Practicum Courses for Biology and Environmental Sciences students. I thank Dieter Ramseier and all participating students for their contributions and enthusiasm. Furthermore, I thank Tino Fotsch for watering the plants, Regina Zäch for her help with harvesting, and Hans Göransson and Stefanie Karrer for conducting a preliminary test. I sincerely thank Sabine Güsewell, Luciola Lannes, Peter Edwards and Mark Gessner for their helpful suggestions to improve the manuscript, and Kristel Perreijn for drawing Fig. 5.

\section{References}

Asmar F, Gissel-Nielsen G (1997) Extracellular phosphomonoand phosphodiesterase associated with and released by roots of barley genotypes: a non-destrcutive method for the measurement of the extracellular enzymes of roots. Biol Fert Soils 25:117-122

Binkley D (1997) Bioassays of the influence of Eucalyptus saligna and Albizia facaltaria on soil nutrient supply and limitation. For Ecol Manag 91:229-234

Cech PG, Kuster T, Edwards PJ, Olde Venterink H (2008) Effects of herbivory, fire and $\mathrm{N}_{2}$-fixation on nutrient limitation in a humid African savanna. Ecosystems 11:991-1004

Chen CR, Condron LM, Davis MR, Sherlock RR (2002) Phosphorus dynamics in the rhizosphere of perrennial ryegrass (Lolium perenne L.) and radiate pine (Pinus radiata d. Don.). Soil Biol Biochem 34:487-499

Elser JJ, Bracken MES, Cleland EE, Gruner DS, Harpole WS, Hillebrand H, Ngai JT, Seabloom EW, Shurin JB, Smith JE (2007) Global analysis of nitrogen and phosphorus limitation of primary producers in freshwater, marine and terrestrial ecosystems. Ecol Lett 10:1135-1142

Fujita Y, Robroek BJM, De Ruiter PC, Heil GW, Wassen MJ (2010) Increased $N$ affects $P$ uptake of eight grassland species: the role of root surface phosphatase activity. Oikos 119:1665-1673

Güsewell S (2005) High nitrogen: phosphorus ratios reduce nutrient retention and second year growth of wetland sedges. New Phytol 166:537-550 
Hayes JE, Richardson AE, Simpson RJ (1999) Phytase and acid phosphatase activities in extracts from roots of temperate pasture grass and legume seedlings. Aust J Plant Physiol 26:801-809

Hogan EJ, Minnullina G, Smith RI, Crittenden PD (2010) Effects of nitrogen enrichment on phosphatase activity and nitrogen: phosphorus relationships in Cladonia portentosa. New Phytol 186:911-925

Houlton BZ, Wang YP, Vitousek PM, Field CB (2008) A unifying framework for dinitrogen fixation in the terrestrial biosphere. Nature 454:327-334

Johnson D, Leake JR, Lee JA (1999) The effects of quantity and duration of simulated pollutant nitrogen deposition on rootsurface phosphatase activities in calcareous and acid grasslands: a bioassay approach. New Phytol 141:433-442

Li M, Osaki M, Rao IM, Tadano T (1997) Secretion of phytase from the roots of several plant species under phosphorusdeficient conditions. Plant Soil 195:161-169

Li SM, Li L, Zhang FS, Tang C (2004) Acid phosphatase role in chickpea/maize intercropping. Ann Bot 94:297-303

Li L, Li SM, Sun JH, Zhou LL, Bao XG, Zhang HG, Zhang FS (2007) Diversity enhances agricultural productivity via rhizosphere phosphorus facilitation on phosphorus deficient soils. P Natl Acad Sci USA 104:11192-11196

McKey D (1994) Legumes and nitrogen: the evolutionary ecology of a nitrogen demanding lifestyle. In: Sprent JI, McKey D (eds) Advances in legume systematics; Part 5 the nitrogen factor. Royal Botanical Gardens, Kew, pp $211-228$

Olde Venterink H, Güsewell S (2010) Competitive interactions between two meadow grasses under nitrogen and phosphorus limitation. Funct Ecol 24:877-886

Perreijn K (2002) Symbiotic nitrogen fixation by leguminous trees in tropical rain forest in Guyana. Tropenbos, Wageningen

Phoenix GK, Booth RE, Leake JR, Read DJ, Grime JP, Lee JA (2004) Simulated pollutant nitrogen deposition increases $P$ demand and enhances root-surface phosphatase activities of three plant functional types in a calcareous grassland. New Phytol 161:279-289

Rejmánková E, Sirová D, Carlson E (2011) Patterns of activities of root phosphomonoesterase and phosphodies- terase in wetland plants as a function of macrophyte species and ambient phosphorus regime. New Phytol. doi:10.1111/j.1469-8137.2011.03652.x

Simon MF, Grether R, de Queiroz LP, Skema C, Pennington RT, Hughes CE (2009) Recent assembly of the Cerrado, a neotropical plant diversity hotspot, by in situ evolution of adaptations to fire. P Natl Acad Sci USA 106:2035920364

Skujijš J, Burns RG (1976) Extracellular enzymes in soil. Crit Rev Microbiol 4:383-421

Ter Steege H, Pitman NCA, Phillips OL, Chave J, Sabatier D, Duque A, Molino JF, Prevost MF, Spichiger R, Castellanos H, Von Hildebrand P, Vasquez R (2006) Continental-scale patterns of canopy tree composition and function across Amazonia. Nature 443:444-447

Treseder KK, Vitousek PM (2001) Effects of soil nutrient availability on investment in acquisition of $\mathrm{N}$ and $\mathrm{P}$ in Hawaiian rain forests. Ecology 82:946-954

Turner BL, Baxter R, Ellwood NTW, Whitton BA (2001) Characterization of phosphatase activities of mosses in relation to their environment. Plant Cell Environ 24:11651176

Vitousek PM, Cassman K, Cleveland C, Crews T, Field CB, Grimm NB, Howarth RW, Marino R, Martinelli L, Rastetter EB, Sprent JI (2002) Towards an ecological understanding of biological nitrogen fixation. Biogeochemistry 57:1-45

Vitousek PM, Porder S, Houlton BZ, Chadwick OA (2010) Terrestrial phosphorus limitation: mechanisms, implications, and nitrogen-phosphorus interactions. Ecol Appl 20:5-15

Wang YP, Houlton BZ, Field CB (2007) A model of biogeochemical cycles of carbon, nitrogen, and phosphorus including symbiotic nitrogen fixation and phosphatase production. Glob Biogeochem Cy 21:GB1018

Yadav RS, Tarafdar JC (2001) Influence of organic and inorganic phosphorus supply on the maximum secretion of acid phosphatase by plants. Biol Fert Soils 34:140-143

Yelenik SG, Stock WD, Richardson DM (2004) Ecosystem level impacts of invasive Acacia saligna in the South African fynbos. Rest Ecol 12:44-51 